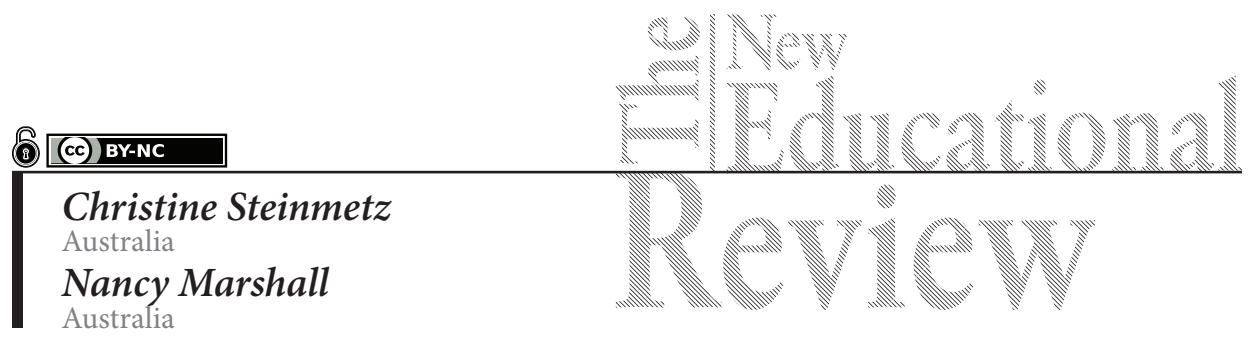

\title{
Australian University Students: Survey of an International Cohort
}

DOI: 10.15804/tner.2021.63.1.01

\begin{abstract}
This research investigated international undergraduate students' needs when adjusting to their new campus, academic and social life. The results from a significant survey of international students provided us with an evidence base to understand the improved student experience this cohort may seek in what will likely be a competitive environment for attracting international students post-COVID-19. While this case study has focused on one faculty, our findings are relevant to higher education institutions across disciplines, domestically and internationally.
\end{abstract}

Key words: International students, Australia, undergraduate, higher education, survey

This research was made possible through the University of New South Wales, Faculty of Built Environment. Steinmetz and Marshall received funding to undertake a topic of their choice relating to the scholarship of learning and teaching in 2017.

\section{Introduction}

There is no doubt that international students are integral to any university; they bring diversity, intercultural learning opportunities and financial resources (Andrade 2006) along with the prestige of having attracted a global audience. This cohort is not only viewed as a significant income source for higher education 
(Forbes-Mewett \& Nyland 2012) but also as an opportunity to exchange knowledge across nations and create a global network of scholars (Roberts and Dunworth 2012). Like Australia, countries such as the United Kingdom, the United States and Canada have recognised the value of economic contributions from international student fees in '[offsetting] declining domestic enrolments and, in turn, improving revenues to their institutions' (James-MacEachern and Yun 2017, p. 344).

Competitive marketing campaigns can confuse international students on points of difference amongst universities (Fleischman, Raciti and Lawley 2015), and 'even the most effective recruiting strategy will only yield limited gains if visiting students do not experience a high-quality, welcoming, and engaging student experience (Smith, Whiteside, Blanchard and Martin 2013, p. 56). At the 2018 Australian Financial Review Higher Education Summit, student experience, particularly for international students, was a high-priority topic. Key speakers warned that the rise of higher education institutions on mainland China and India threaten Australia's intake of international students from the Asia-Pacific region, ending the status quo and signalling that Australian universities can no longer assume that a 'Western' education will be the first choice for these students.

Enter 2020 and COVID-19. In 2019, approximately 420,000 international students accounted for 24 per cent of the total undergraduate student population in Australian universities (Australian Department of Education and Training 2019). In early 2021, enrolments were reported down 14 per cent from 2020 (Australia's Department of Education Skills and Employment Research Snapshot 2021) with further predictions about enrolments in 2021 seeming unwarranted as long as border controls and limited entry to overseas travellers remain in situ for Australian capital cities. Causing more than a slight jolt to the system, the pandemic interrupted a 70-year run of increasing international student enrolments on Australian shores.

Since COVID-19, universities, especially in Australia, have realised the extent to which their reliance on international student fees provided a false economy of stability and deep pockets. And while enrolments may remain low for the time being, it will serve our universities well to leap ahead, to discover what was working for international students pre-COVID and to be prepared to offer international students the additional opportunities and services they feel are needed to support their academic and social success. Preparing now for these improvements will position our universities to be attractive and competitive as international students consider their options when returning to foreign soils.

The research on the academic and social needs of international students which is presented in this article was conducted in the Faculty of Built Environment at 
the University of New South Wales Sydney (UNSW), a member of the Group of Eight (Go8) coalition of research-intensive universities. A faculty-wide quantitative and qualitative survey was distributed to all enrolled international students $(\mathrm{N}=753)$ in late 2017. In that year, the faculty hosted 2367 undergraduate students (753 international and 1614 local), the largest survey conducted with international students within the faculty since its inception sixty-three years ago.

\section{International undergraduate student experiences}

International students leave their country of origin to undertake a set course of study in another country, to learn a new language, or to gain an understanding of diverse cultural practices (Andrade 2006). Although they bring with them a host of challenges, both personally and academically (Lin 2012), they add a rich layer of dialogue in our classrooms, contribute to campus engagement through clubs and other social activities, and are part of 'diversifying and enriching communities, and strengthening Australia's global networks' (Belford 2017, p. 499). Australia is no different to other countries with significant numbers of international students in being confronted with challenges inherent in any cross-cultural educational experience, such as academic, acculturative and life stress, lack of social support, and low identification with the host culture' (Zhang and Goodson 2011, p. 614).

Four key areas that framed the student survey are discussed below: arrival and orientation; interaction with faculty members and other students; academic skill gaps; and the support services needed to help international students settle into a new country and succeed in their academic endeavours.

\section{Arrival and orientation}

At the start of a new term or semester, most universities provide students with an Open Day or as much as a full week of orientation activities on campus. Cowley and Hyams-Ssekasi (2018, p. 123) contend that 'international students are potentially dependent on the induction week to receive information relevant for key non-academic issues.' These activities are generally aimed at new students to assist with their integration into the student community and to mitigate feelings of isolation for those arriving from overseas (Coles and Swami 2012). This orientation allows students to participate in campus tours, engage with student ambassadors, and familiarise themselves with the campus layout and environment and with the 


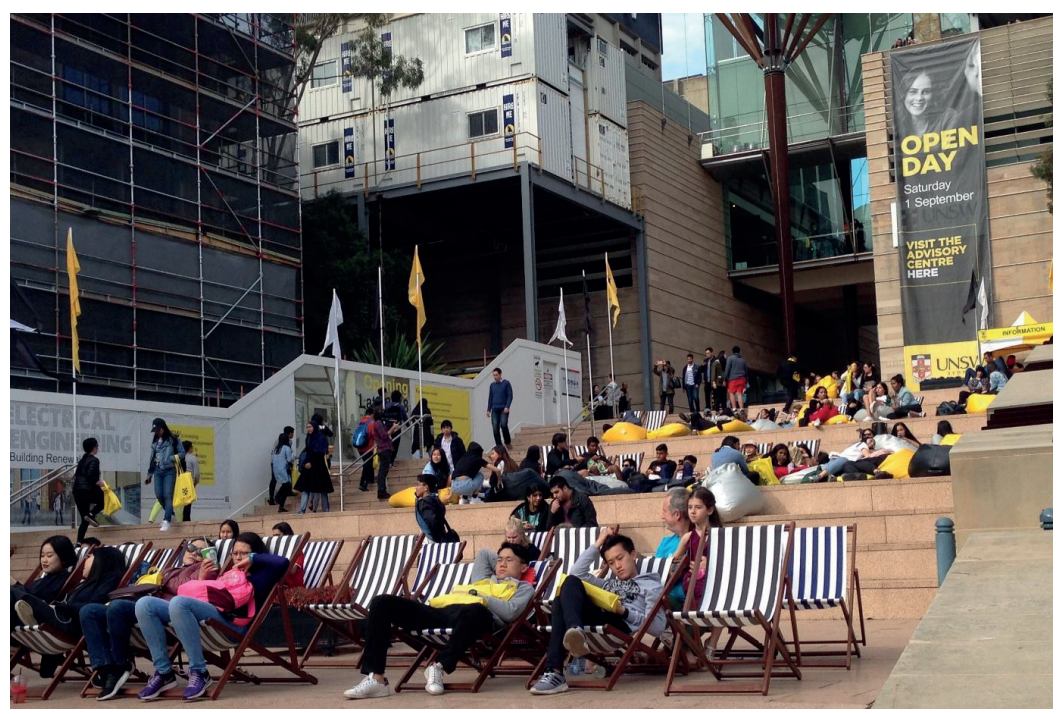

Figure 1: Open Day at UNSW Sydney (Marshall 2018).

services available on campus. Doing this prior to the start of classes is one way to decrease or alleviate anxiety related to a new and unfamiliar place.

\section{Interaction with faculty and students}

International students often rely heavily on fixed institutional support mechanisms (i.e., learning centres, counselling services), and academic staff are perceived to be part of that overall support system (Myles and Cheng 2003). Positive relationships with academics not only contribute to students' scholastic achievements but also have a direct impact on their overall motivation.

International students' social networks often consist of international students from the same geographic region as well as local students with cultural similarities. Hardships experienced by international students are not always culturally bound. Difficult situations such as loneliness or financial stress can be a common ground (Yan and Sendall 2016) as well as navigating new environments in a foreign landscape. Regardless of fundamental challenges, whether cultural, linguistic, or financial or in building new relationships, connecting with people on a deep and meaningful level is vital to having a positive experience as an international student (Rosenthal, Russell and Thomson 2007). 


\section{Academic skill gaps}

Difficulty with English language proficiency is a barrier for international university students (Wu, Garza and Guzman 2015), as students may find that spoken English in their host country is much different from the English instruction they learned at home 'especially its rules, exceptions, and regional discrepancies' (Perry et al. 2017, p. 281). Whether the difficulty understanding English is in a written or spoken form, lack of comprehension can create academic barriers and undermine a student's purpose for undertaking a degree program in another language. Lin (2012) contends that international students may shy away from interacting with their teachers because they feel their language skills are not good enough.

While students may be well-versed in academic language, they may lack the confidence or 'words' to interact socially (Lacina 2002). Challenges with the pace of speech, pronunciation and accents are also considered to be social and academic barriers for international students (Wu, Garza and Guzman 2015). For international students to be 'well prepared for social interaction, they need to be familiar with idioms and college slang as well as proficient in academic English' (Lacina 2002, p. 22), even though competency and fluency do not always equate to academic success (Jones 2017). Language barriers may contribute to difficulty in interacting with local students, prompting some students, particularly undergraduates, to avoid socialising with English-speaking students altogether (Gomes, Berry, Alzougool and Chang 2014) even though social interaction with local students provides opportunities for international students to learn different communication patterns firsthand through observation, practice, and feedback (Belford 2017).

\section{$\underline{\text { Support services }}$}

Typical university services include academic or learning support, advice on financial or legal affairs, counselling and, for larger universities, a dedicated international hub or even a building. Research has shown that while international students were aware of services on campus, the extent to which they understood what the services were for emerged as the real problem. Usefulness, access and barriers to use were reasons why international students perceived support services to be somewhat confusing and overloaded with information (Roberts and Dunworth 2012). Universities are advised to make these services easily accessible and widely promoted to a cohort who may be unaware of their availability (Martirosyan, Bustamante and Saxon 2019). 
Because of 'different student learning experiences, associated expectations and needs, along with English often being their second language, a tailored support program needs to be designed and implemented' (Coates and Dickinson 2012, p. 306). Indeed, Coates and Dickerson contend that learning support services should be woven into a formally assessed course structure as part of a degree program (2012). For example, 'using technology to automate routine information gathering and dissemination ... can free up precious staff time for more meaningful and personal engagement with students' (Wheelan 2016, p. 40).

\section{Methods}

Informed by various higher education survey instruments, a questionnaire was developed for the 743 international undergraduate students enrolled in the Faculty of Built Environment at UNSW Sydney in the fall of 2017. The invitation email included a brief description of the project, aims of the research, evidence of ethical clearance from the UNSW Human Research Ethics Committee, and contact information for both chief investigators. Instructions were succinct and asked participants to complete the questionnaire and return it by email to the chief investigators. The survey had 42 questions in total, comprised of 32 Likert-scale questions (strongly agree, agree, disagree, strongly disagree, not applicable) and 10 closed or short-answer questions. Eight weeks after the project began, a total of 340 questionnaires had been completed for an overall response rate of 46 per cent. The survey focused on the student's arrival in Australia, interactions with academics and peers, skills capacity, student support services, and overall wellbeing.

\section{Questionnaire findings}

The questionnaire was divided into six sections and analysed via SPSS as shown in Tables 1 to 5. For ease of reading, percentages have been rounded. Of the respondents, 90 per cent had been living in Australia for five years or less, 8 per cent for five to ten years, and 2 per cent for more than ten years. Eighty-three per cent of students were in their first three years of undergraduate study.

For a sizeable proportion of respondents, their arrival in Australia was made easier by the university's orientation week and the provision of information by the 
Table 1. Arrival to Australia and orientation to university life

\begin{tabular}{llcccc}
\hline \multicolumn{1}{c}{ Statement } & $\begin{array}{c}S A \\
(\%)\end{array}$ & $\begin{array}{c}A \\
(\%)\end{array}$ & $\begin{array}{c}D \\
(\%)\end{array}$ & $\begin{array}{c}S D \\
(\%)\end{array}$ & N/A \\
\hline Orientation at UNSW was helpful & 15 & 71 & 9 & 1 & 4 \\
\hline $\begin{array}{l}\text { Orientation in the Faculty of Built Environment was } \\
\text { helpful }\end{array}$ & 13 & 66 & 11 & 2 & 8 \\
\hline $\begin{array}{l}\text { UNSW was helpful in providing information about arriv- } \\
\text { ing to the university }\end{array}$ & 21 & 65 & 8 & 1 & 6 \\
\hline $\begin{array}{l}\text { The UNSW website was helpful when settling in } \\
\text { My parents were influential in my decision to study in }\end{array}$ & 21 & 56 & 13 & 1 & 2 \\
\hline \begin{tabular}{l} 
Australia \\
\hline
\end{tabular} & & & 18 & 5 & 7 \\
\hline
\end{tabular}

university outside of orientation, both at 86 per cent agreement (agreed or strongly agreed), followed closely by the university website, at 83 per cent. Orientation within the faculty was also helpful, at 79 per cent. Although not directly related to arrival, about 70 per cent of respondents agreed their parents influenced their decision to study in Australia.

Table 2. Interacting with faculty academics

\begin{tabular}{lccccc}
\hline \multicolumn{1}{c}{ Statement } & $\begin{array}{c}S A \\
(\%)\end{array}$ & $\begin{array}{c}A \\
(\%)\end{array}$ & $\begin{array}{c}D \\
(\%)\end{array}$ & $\begin{array}{c}S D \\
(\%)\end{array}$ & N/A \\
\hline I find it easy to talk to my teachers & 17 & 70 & 12 & 0 & 1 \\
\hline I have adequate access to my teachers & 18 & 66 & 12 & 2 & 2 \\
\hline My teachers are friendly & 34 & 60 & 4 & 0 & 2 \\
\hline I understand what is expected of me in my classes & 20 & 69 & 9 & 1 & 0 \\
\hline I understand what is expected of my assignments & 20 & 66 & 12 & 2 & 0 \\
\hline
\end{tabular}

A positive outcome of the data revealed that 94 per cent of students agreed that their teachers were friendly, and 87 per cent felt that their teachers were easy to talk to. In terms of academic success, 89 per cent of students believed they understood what was expected of them in class, and 86 per cent understood what was expected of them on their assignments. The survey showed that 14 per cent of international undergraduate students did not feel they had sufficient access to their teachers. The same proportion did not understand their assignments and slightly fewer were not sure of what was expected of them in class. 
Table 3. Interacting with international students

\begin{tabular}{lccccc}
\hline \multicolumn{1}{c}{ Statement } & $\begin{array}{c}S A \\
(\%)\end{array}$ & $\begin{array}{c}A \\
(\%)\end{array}$ & $\begin{array}{c}D \\
(\%)\end{array}$ & $\begin{array}{c}S D \\
(\%)\end{array}$ & N/A \\
\hline $\begin{array}{l}\text { I talk mostly with international students from my } \\
\text { home country }\end{array}$ & 32 & 41 & 20 & 5 & 2 \\
\hline $\begin{array}{l}\text { I prefer to do assigned group work with other interna- } \\
\text { tional students }\end{array}$ & 19 & 42 & 32 & 4 & 3 \\
\hline $\begin{array}{l}\text { I rely heavily on other international students for emo- } \\
\text { tional support and friendship }\end{array}$ & 17 & 42 & 31 & 7 & 3 \\
\hline I feel isolated from other international students & 4 & 20 & 46 & 23 & 7 \\
\hline
\end{tabular}

A total of 73 per cent of the students surveyed talked mostly with international students from their home country, and 59 per cent relied heavily on other international students for friendship and emotional support. Aligned with this, 61 per cent of students preferred to work with other international students on group assignments. However, almost one quarter of these students (24 per cent) felt isolated from other international students. The survey confirmed strong connections to other international students for friendship, emotional support, and academic collaboration. Many respondents also socialized with Australian students and felt confident in communicating with them. The 85 per cent of students who longed for more opportunities to socialise with local and other international students highlighted a shortcoming in the ability or opportunity, either inside class or outside, to interact on a social basis.

Table 4. Interacting with Australian students

\begin{tabular}{lccccc}
\hline \multicolumn{1}{c}{ Statement } & $\begin{array}{c}S A \\
(\%)\end{array}$ & $\begin{array}{c}A \\
(\%)\end{array}$ & $\begin{array}{c}D \\
(\%)\end{array}$ & $\begin{array}{c}S D \\
(\%)\end{array}$ & N/A \\
\hline I socialise with Australian students & 10 & 56 & 28 & 3 & 3 \\
\hline $\begin{array}{l}\text { I learn a lot about Australia and its culture from local } \\
\text { students }\end{array}$ & 14 & 43 & 37 & 4 & 2 \\
\hline I feel confident when speaking with Australian students & 13 & 52 & 29 & 3 & 3 \\
\hline $\begin{array}{l}\text { My English has improved since studying in the [Built } \\
\text { Environment] faculty }\end{array}$ & 17 & 56 & 17 & 3 & 7 \\
\hline \begin{tabular}{l} 
I feel welcome when interacting with Australian students \\
\hline
\end{tabular} & 13 & 64 & 15 & 2 & 6 \\
\hline
\end{tabular}

A total of 77 per cent of international students felt welcome when interacting with Australian students. Perhaps as a result, 66 per cent socialized with Australian students, and 65 per cent felt confident when speaking to them. Yet only 57 per 
cent felt they learned a lot about Australia and its culture from their local counterparts. Although 73 per cent of international students believed their English had improved since they began studying in the faculty, 20 per cent disagreed or strongly disagreed.

Table 5. Support services needed

\begin{tabular}{|c|c|c|c|c|c|}
\hline Statement & $\begin{array}{l}S A \\
(\%)\end{array}$ & $\begin{array}{c}A \\
(\%)\end{array}$ & $\begin{array}{l}D \\
(\%)\end{array}$ & $\begin{array}{l}S D \\
(\%)\end{array}$ & $N / A$ \\
\hline I need help with note taking in my classes & 10 & 33 & 42 & 10 & 5 \\
\hline $\begin{array}{l}\text { I need extra help with understanding the lecture content } \\
\text { of my classes }\end{array}$ & 12 & 31 & 43 & 11 & 3 \\
\hline I can easily get through all the required reading for class & 14 & 47 & 30 & 4 & 5 \\
\hline $\begin{array}{l}\text { Additional tutorials in speaking English would help me } \\
\text { with my studies }\end{array}$ & 19 & 44 & 27 & 4 & 6 \\
\hline $\begin{array}{l}\text { Additional tutorials in helping understand the feedback on } \\
\text { my assignments would help me with my studies }\end{array}$ & 24 & 52 & 19 & 2 & 3 \\
\hline $\begin{array}{l}\text { Support in drawing/graphic skills would help me with my } \\
\text { studies }\end{array}$ & 36 & 50 & 10 & 2 & 2 \\
\hline Support in writing skills would help me with my studies & 31 & 51 & 13 & 1 & 4 \\
\hline $\begin{array}{l}\text { UNSW health services and health/well-being counsellors } \\
\text { are helpful to me }\end{array}$ & 16 & 48 & 16 & 3 & 17 \\
\hline UNSW Learning Centre and its website are helpful to me & 16 & 56 & 15 & 1 & 12 \\
\hline $\begin{array}{l}\text { Faculty [Built Environment] Student Centre is helpful to } \\
\text { me }\end{array}$ & 20 & 66 & 8 & 0 & 6 \\
\hline $\begin{array}{l}\text { Faculty [Built Environment] Computing Unit is helpful to } \\
\text { me }\end{array}$ & 15 & 57 & 15 & 1 & 12 \\
\hline $\begin{array}{l}\text { I would like opportunities to engage socially with other } \\
\text { international students }\end{array}$ & 27 & 59 & 10 & 0 & 4 \\
\hline $\begin{array}{l}\text { I would like opportunities to engage socially with Austral- } \\
\text { ian students }\end{array}$ & 31 & 56 & 9 & 1 & 3 \\
\hline
\end{tabular}

According to the findings, our international students would like additional tutorials in speaking English (63 per cent) and in understanding feedback on assignments (76 per cent), while 82 per cent would like support to improve their writing skills. This likely reflects the findings that 34 per cent of our faculty's international students cannot easily get through assigned class readings, 43 per cent need help with taking notes in class, and 43 per cent need help with understanding lectures. A sizable portion of our international students need support to improve their written and oral English language skills to increase comprehension. In terms 
of support, 61 per cent of international students surveyed could easily get through assigned class readings, whereas 34 per cent could not. In addition, 82 per cent would like support to improve their writing skills, and 86 per cent would like similar help with drawing or graphic design skills.

Most universities, if not all, offer services designed specifically for students. These services are typically housed in a student union building or as a group of administrative offices separate from learning spaces. Services include counselling centres, health clinics, religious spaces, and tutorial and legal centres. The survey found that while 86 per cent of students felt the faculty Student Centre was helpful, only 72 per cent found the faculty Computing Centre or the university's Learning Centre to be helpful. Of those surveyed, merely 64 per cent found the university's health services and counsellors to be helpful. Given the high to extreme stress levels amongst 62 per cent of our international students, ensuring those services are meeting their needs is critical. However, the extent to which students understand the services and offerings and whether or not they are 'free to use' as a student is unknown.

\section{Conclusions}

This research surveyed almost half of our 743 students in late 2017 to assess key areas of student support identified in the literature and in student-satisfaction surveys. While most students seemed to be doing well socially and academically, there were some surprising outcomes. The university provided sufficient resources and support for international students as they commenced their studies. Teachers were friendly, and students reported that they were accessible and approachable. Although those surveyed were confident in talking with local students and with other international students, they reported that there were not enough opportunities to do so and, therefore, lacked cultural knowledge about Australia. Academic support services were recognised as being available, but the students reported that they need more assistance with basic skills such as writing, notetaking and drawing. This snapshot of international students highlights another key messagethat this cohort wants added opportunities to engage with local students and the culture. The survey data can be used by faculties and universities to attract, support and guide international students post-COVID-19 who may be better informed of their needs and requirements for achieving academic achievement after having experienced a year of uncertainty and social isolation in their at-home university experience. 


\section{References}

Andrade, M. S. (2006). International students in English-speaking universities: Adjustment factors. Journal of Research in International Education 5(2), 131-154.

Australian Government Department of Skills and Employment (2021). https://internationaleducation.gov.au/research/research-snapshots/Documents/RS_2021ReturningStudents.pdf Accessed January 25, 2021.

Australian Government Department of Skills and Employment (2019). Available at: http:// internationaleducation.gov.au/research/International-Student-Data/ Accessed January 25, 2021.

Belford, N. (2017). International students from Melbourne describing their cross-cultural transitions experiences: Culture shock, social interaction, and friendship development. Journal of International Students 7(3), 499-521.

Chen, L.H. (2008). Internationalization or international marketing? Two frameworks for understanding international students' choice of Canadian universities. Journal of Marketing for Higher Education 18(1), 1-33.

Coates, N., and Dickinson, J. (2012). Meeting international postgraduate student needs: A programme-based model for learning and teaching support. Innovations in Education and Teaching International 49(3), 295-308.

Coles, R., and Swami, V. (2012). The sociocultural adjustment trajectory of international university students and the role of university structures: A qualitative investigation. Journal of Research in International Education 11(1), 87-100.

Cowley, P., and Hyams-Ssekasi, D. (2018). Motivation, induction, and challenge: Examining the initial phase of international students' educational sojourn. Journal of International Studies 8(1), 109-130.

Fleischman, D., Raciti, M., and Lawley, M. (2015). Degrees of co-creation: An exploratory study of perceptions of international students' role in community engagement experiences. Journal of Marketing for Higher Education 25(1), 85-103.

Forbes-Mewett, H., and Nyland, C. (2012). Funding international student support services: Tension and power in the university. Higher Education 65, 181-192.

Gomes, C., Berry, M., Alzougool, B., and Chang, S. (2014). Home away from home: International students and the identity-based social networks in Australia. Journal of International Students 4(1), 2-15.

James-MacEachern, M., and Yun, D. (2017). Exploring factors influencing students' decision to choose a higher education institution: A comparison between Chinese and other students. International Journal of Educational Management 31(3), 343-363.

Jones, E. (2017). Problematising and reimagining the notion of 'international student experience'. Studies in Higher Education 42 (5), 933-943.

Lacina, J. (2002). Preparing international students for a successful social experience in higher education. New Directions for Higher Education 117, 21-27.

Lin, M. (2012). Students of different minds: Bridging the gaps of international students studying in the US. US-China Education Review A (3), 333-344. 
Martirosyan, N.M., Bustamante, R., and Saxon, D.P. (2019). Academic and social support services for international students. Journal of International Students 9(1), 172-191.

Myles, J., and Cheng, L. (2003). The social and cultural life of non-native English speaking international graduate students a Canadian university. Journal of English for Academic Purposes 2(3), 247-263.

Perry, C.J., Lausch, D.W., Weatherford, J., Goeken, R., and Almendares, M. (2017). International students' perceptions of university life. College Student Journal 51(2), 279-290.

Roberts, P., and Dunworth, K. (2012). Staff and student perceptions of support services for international students in higher education: A case study. Journal of Higher Education Policy and Management 34(5), 517-528.

Rosenthal, D.A., Russell, J., and Thomson, G. (2008). The health and wellbeing of international students at an Australian university. Higher Education 55(1), 51-67.

Rosenthal, D.A., Russell, J., and Thomson, G. (2007). Social connectedness among international students at an Australian university. Social Indicators Research 84(1), 71-82.

Smith, C., Whiteside, B., Blanchard, S., and Martin, C. (2013) 'International student support services at Ontario universities. Strategic Enrollment Management Quarterly 1(1), 55-66.

Wheelan, P. (2016). Flipping student support services to improve outcomes. Change: The Magazine of Higher Learning 48(6), 36-41.

Wu, H., Garza, E., and Guzman, N. (2015). International student's challenge and adjustment to college. Educational Research International (2015), 1-9.

Yan, Z., and Sendall, P. (2016). First year experience: How we can better assist first-year international students in higher education. Journal of International Students 6(1), 35-51.

Zhang, J., and Goodson, P. (2011). Acculturation and psychosocial adjustment of Chinese international students: Examining mediation and moderation effects. International Journal of Intercultural Relations 35(5), 614-627. 